\title{
HPAC Validation against NRC Documentation
}

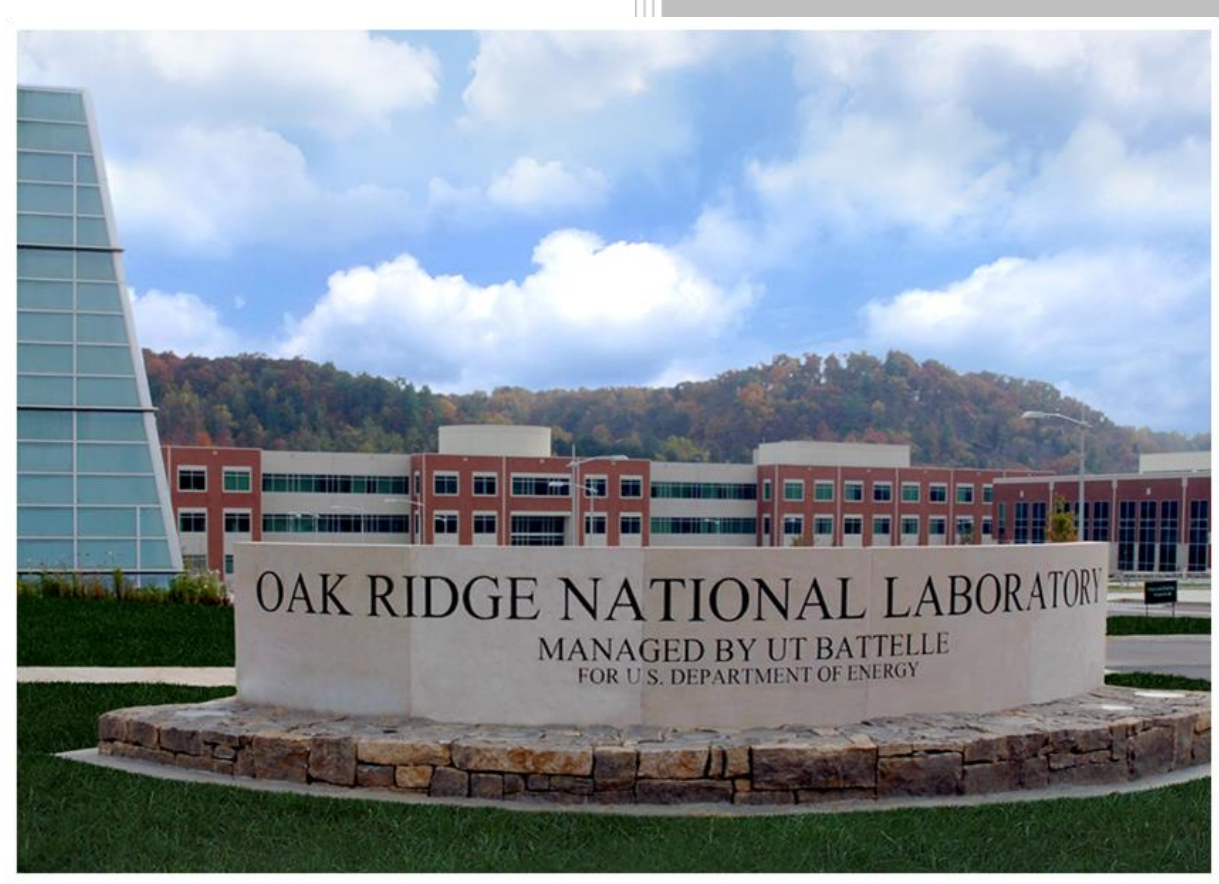

Approved for public release. Distribution is unlimited.

C. David Sulfredge

Ronald W. Lee

November 2020 


\title{
DOCUMENT AVAILABILITY
}

Reports produced after January 1, 1996, are generally available free via US Department of Energy (DOE) SciTech Connect.

Website www.osti.gov

Reports produced before January 1, 1996, may be purchased by members of the public from the following source:

\author{
National Technical Information Service \\ 5285 Port Royal Road \\ Springfield, VA 22161 \\ Telephone 703-605-6000 (1-800-553-6847) \\ TDD 703-487-4639 \\ Fax 703-605-6900 \\ E-mail info@ntis.gov \\ Website http://classic.ntis.gov/
}

Reports are available to DOE employees, DOE contractors, Energy Technology Data Exchange representatives, and International Nuclear Information System representatives from the following source:

Office of Scientific and Technical Information

PO Box 62

Oak Ridge, TN 37831

Telephone 865-576-8401

Fax 865-576-5728

E-mail reports@osti.gov

Website http://www.osti.gov/contact.html

This report was prepared as an account of work sponsored by an agency of the United States Government. Neither the United States Government nor any agency thereof, nor any of their employees, makes any warranty, express or implied, or assumes any legal liability or responsibility for the accuracy, completeness, or usefulness of any information, apparatus, product, or process disclosed, or represents that its use would not infringe privately owned rights. Reference herein to any specific commercial product, process, or service by trade name, trademark, manufacturer, or otherwise, does not necessarily constitute or imply its endorsement, recommendation, or favoring by the United States Government or any agency thereof. The views and opinions of authors expressed herein do not necessarily state or reflect those of the United States Government or any agency thereof. 
Computational Sciences and Engineering Division

Computer Science and Mathematics Division

\title{
HPAC Validation against NRC Documentation
}

\author{
C. David Sulfredge \\ Ronald W. Lee
}

Date Published: November 2020

\author{
Prepared by \\ OAK RIDGE NATIONAL LABORATORY \\ Oak Ridge, TN 37831-6283 \\ managed by \\ UT-BATTELLE, LLC \\ for the \\ US DEPARTMENT OF ENERGY \\ under contract DE-AC05-00OR22725
}




\section{CONTENTS}

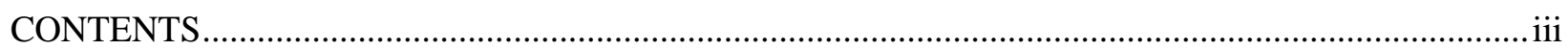

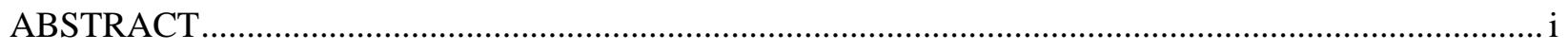

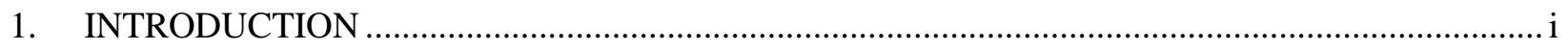

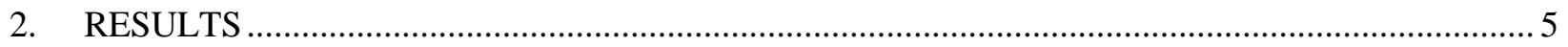

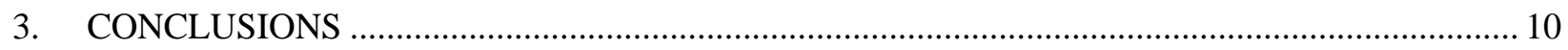

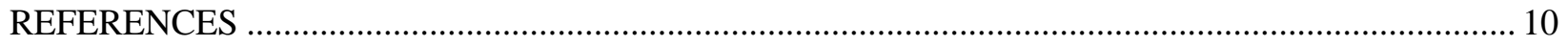




\section{LIST OF FIGURES}

1 File acspwr.dat which defines the isotopic release fractions for a PWR severe accident in NFAC...

2 File acmpwr.dat which defines the isotopic release fractions for a PWR moderate accident in NFAC...

3 File acsbwr.dat which defines the isotopic release fractions for a BWR severe accident in NFAC

4 File acmbwr.dat which defines the isotopic release fractions for a BWR moderate accident in NFAC.

5 Definitions and isotopic compositions for the MELCOR groups in NFAC.

6 Release fractions and timing for a small LOCA with early containment failure from the Calvert Cliffs IPE report

7 Release fractions and timing for a LOCA with late containment failure from the Calvert Cliffs IPE report.

8 Release fractions and timing for a severe accident at Grand Gulf, from an NRC-sponsored ORNL report.

9 Release fractions and timing from a generic PWR severe accident, from NRC NUREG-1465.

10 Release fractions and timing from a generic BWR severe accident, from NRC NUREG-1465 


\begin{abstract}
This report describes validation of the radiological source terms in the Nuclear Facility Accident (NFAC) module of the Defense Threat Reduction Agency (DTRA)'s Hazard Prediction and Assessment Capability (HPAC) software. The validation will be conducted by comparing the source terms defined in HPAC to published data from references approved by the U. S. Nuclear Regulatory Commission (NRC). Comparisons will be done for both pressurized water reactors (PWRs) and boiling water reactors (BWRs). This comparison includes the magnitude, isotopic composition, and timing of the release fractions over the course of a severe or moderate accident. Calculations for both facility-specific nuclear power plants and for more generic reactor categories are involved. It is shown that the NFAC radiological source terms in HPAC agree well with NRC standards for moderate and severe accidents at PWRs and BWRs.
\end{abstract}

\title{
1. INTRODUCTION
}

The purpose of this report is to validate the source terms generated by HPAC's NFAC module for PWRs and BWRs against published NRC information. Magnitudes and timings for isotopic releases in severe and moderate accidents are defined in NFAC by the files acspwr.dat and acmpwr.dat (for PWRs) or acsbwr.dat and acmbwr.dat (for BWRs). The text of these files is presented in Figures 1-4. In order to understand these files, one also needs to know how the isotopes are organized into groups associated with the NRC's MELCOR (Methods for Estimation of Leakages and Consequences of Release) code, as shown in Figure 5. There are a total of 13 MELCOR groups including \#1 (Noble Gases), \#2 (Alkali Metals), and \#4 (Halogens).

Each accident definition file consists of a series of releases and timings broken down by MELCOR group. The first column shows release percentages for MELCOR group \#1 (the Noble Gases), the second column shows releases for MELCOR group \#2 (the Alkali Metals), etc. The last column gives the duration of each release increment in minutes. As an example, for PWR severe accident file acspwr.dat in Figure 1, the first release line with all zeros and a duration of $150 \mathrm{~min}$ indicates a 150-minute delay before any releases begin. The next line shows that $8 \%$ of MELCOR group \#1 (Noble Gases), none of MELCOR group \#2 (Alkali Metals), and 2\% of MELCOR group \#4 (Halogens) plus minor amounts from Groups 3, 6, 8 and 9, are released over the next 60 minutes. The total PWR severe accident release from the file in Figure 1 includes three more such release increments. 
PWR severe accident release from MAAP calculation for Calvert Cliffs pWR plant, Small Early Containment Failure accident. The release starts at the time of vessel melt-through, which occurs at about 3.2 hours. Since the containment has already failed at this time, most of the release occurs within the next 5 hours. The release of cesium and iodine indicates a gradual and continuous release behavior.

Reference is from Calvert Cliffs Nuclear Power Plant, Individual Plant Examination (IPE), Summary Report, by Baltimore Gas and Electric, December 1993, pp. 4.7-1 - 4.7-20.

700
0
8
29
44
16

$\begin{array}{rr}5 & \\ 0 & 0 \\ 0 & 0.001 \\ 0.5 & 0.013 \\ 2.5 & 0.0105\end{array}$

$\begin{array}{rr}0 & 0 \\ 001 & 2 \\ 013 & 8 \\ 105 & 9 \\ 0 & 0\end{array}$

$\begin{array}{rr}0 & 0 \\ 0 & 0.00045 \\ 3 & 0.00055 \\ 39.5 & 0.0009 \\ 13.5 & 0\end{array}$

$\begin{array}{rrr}0 & 0 & 0 \\ 0 & 0.00002 & 0.0045 \\ 0 & 0.00006 & 0.0035 \\ 0 & 0.00025 & 0.0125 \\ 0 & 0.00007 & 0.0005\end{array}$

0
0
0
0
0

0
0
0
0
0

$\begin{array}{lrl}0 & 150 \mathrm{~min} \\ 0 & 60 \mathrm{~min} \\ 0 & 90 \mathrm{~min} \\ 0 & 300 \mathrm{~min} \\ 0 & 1500 \mathrm{~min}\end{array}$

Figure 1. File acspwr.dat which defines the isotopic release fractions for a PWR severe accident in NFAC.

PWR moderate accident release from MAAP calculation for Calvert Cliffs PWR plant, Late Containment Failure accident. The release starts at the time of vessel melt-through, which occurs at about 3.2 hours. At 36.4 hours,

the containment fails with a leak failure mode due to overpressure and the release rate accelerates. The low release fraction for the noble gases indicates that only about 208 of the containment atmosphere has been released 10 hours after containment failure.

Reference is from Calvert Cliffs Nuclear Power Plant, Individual Plant Examination (IPE), Summary Report, by Baltimore Gas and Electric, December 1993, pp.4.7-1 - 4.7-20.

$\begin{array}{rrrrrr}2700 & 4 & & & & \\ 0 & 0 & 0 & 0 & 0 & 0 \\ 3 & 0.003 & 0.00001 & 0.003 & 0.03 & 1.2 \mathrm{E}-07 \\ 3 & 0.003 & 0 & 0.003 & 0.03 & 1.68 \mathrm{E}-06 \\ 17 & 0.07 & 8.95 \mathrm{E}-05 & 0.089 & 0.64 & 6.2 \mathrm{E}-06\end{array}$

Figure 2. File acmpwr.dat which defines the isotopic release fractions for a PWR moderate accident in NFAC. 
BWR Grand Gulf station Blackout Severe Accident based on ORNL MELCOR calculation.

Calculation used best estimate input deck with lower plenum debris bed package.

Clad Failure at $81 \mathrm{~min}$, Vessel Failure at $287.9 \mathrm{~min}$, Containment Failure at 2,580.45 min

Calculation End Time is 47.2 hours.

Reference is ORNL/TM-12771, Comparison of MELCOR MOdeling Techniques and Effects of Vessel Water

Injection on a Low-Pressure, Short-Term, Station Blackout at the Grand Gulf Nuclear Station, June 1995 .

$\begin{array}{rrrrr}3833 & 5 & & & \\ 0 & 0 & 0 & 0 & 0 \\ 63.7 & 0.3 & 0.0001 & 0.48 & 0.09 \\ 11 & 0.4 & 0 & 0.43 & 0.09 \\ 5.3 & 0.2 & 0 & 0.27 & 0.06 \\ 4.6 & 0.1 & 0 & 0.17 & 0.04\end{array}$

Figure 3. File acsbwr.dat which defines the isotopic release fractions for a BWR severe accident in NFAC.

BWR Grand Gulf Small Break Loss of Coolant (LOCA)

Moderate Accident based on ORNL MELCOR calculation.

Clad Failure at $29.5 \mathrm{~min}$, Vessel Failure at $172.8 \mathrm{~min}$, no Containment Failure

Calculation End Time is 12 hours

Reference is ORNL/NRC/LTR-98/17 "MELCOR Small Break LOCA Calculations," March 1999. $---$

$\begin{array}{rrrrr}3833 & 5 & & & 0 \\ 0 & 0 & 0 & 0 & 0.35 \\ 0.01 & 0.6 & 0 & 0 & 0.35 \\ 0.09 & 1.7 & 0.03 & 0 & 1.45 \\ 0.8 & 0.9 & 0 & 0 & 0.45 \\ 0.3 & 0.1 & 0 & 0 & 0.22\end{array}$

$\begin{array}{rll}0 & 0 & 0 \\ .35 & 0 & 0 \\ .45 & 0 & 0 \\ .45 & 0 & 0 \\ .22 & 0 & 0\end{array}$

$\begin{array}{rr}0 & 0 \\ 0.003 & 0.002 \\ 0.001 & 0.001 \\ 0 & 0 \\ 0.001 & 0.001\end{array}$

$2580 \mathrm{~min}$

$40 \mathrm{~min}$

$17 \mathrm{~min}$

$74 \mathrm{~min}$

$123 \mathrm{~min}$

Figure 4. File acmbwr.dat which defines the isotopic release fractions for a BWR moderate accident in NFAC. 


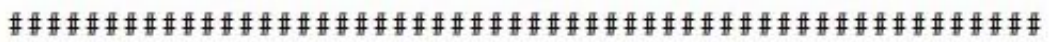

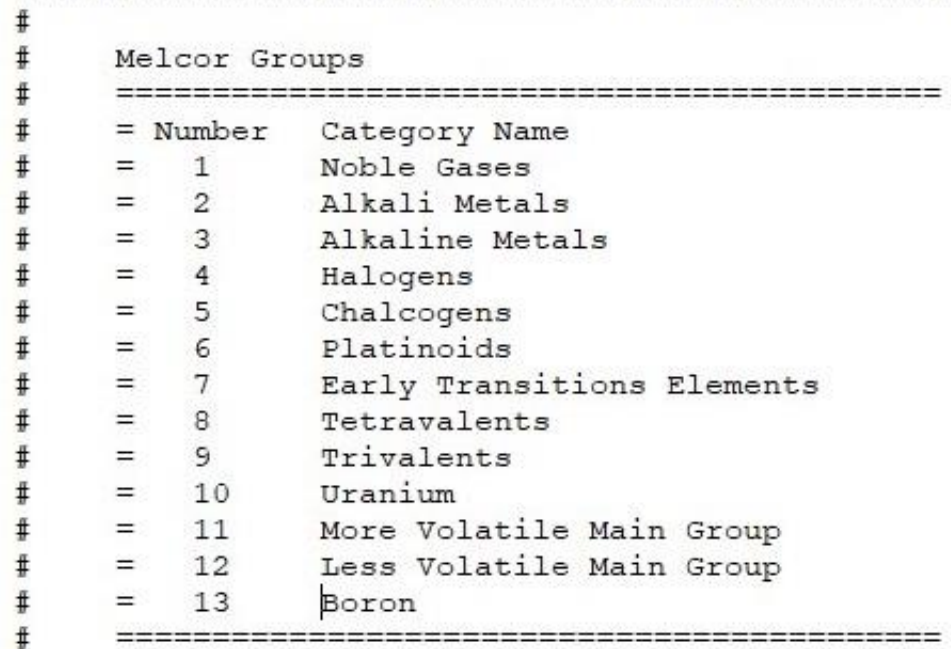

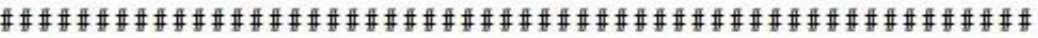

\# Number

Elements

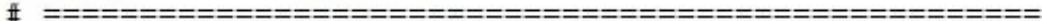

"Xe, He, Ne, Ar, Kr, Rn, H, N"

"Cs, Li, $\mathrm{Na}, \mathrm{K}, \mathrm{Rb}, \mathrm{Fr}, \mathrm{Cu}$

"Ba, $\mathrm{Be}, \mathrm{Mg}, \mathrm{Ca}, \mathrm{Sr}, \mathrm{Ra}, \mathrm{Es}, \mathrm{Fm}, \mathrm{Md}$, No"

"I, $\mathrm{F}, \mathrm{Cl}, \mathrm{Br}, \mathrm{At} "$

"Te, O, S, Se, Po"

"Ru, Rh, Pd, Re, Os, Ir, Pt, $\mathrm{Au}, \mathrm{Ni}, \mathrm{Ds}, \mathrm{Rg} "$

"Mo, $\mathrm{V}, \mathrm{Cr}, \mathrm{Fe}, \mathrm{C} \circ, \mathrm{Mn}, \mathrm{Nb}, \mathrm{TC}, \mathrm{Ta}, \mathrm{W}, \mathrm{Db}, \mathrm{Sg}, \mathrm{Bh}, \mathrm{Hs}, \mathrm{Mt}$

"Ce, Ti, Zr, Hf, Th, Pa, Np, Pu, C, Rf"

"La, Al, Sc, Y, Ac, Pr, Nd, Pm, Sm, Eu, Gd, Tb, Dy, Ho, Er, Tm, Yb, Lu, Am, Cm, Bk, Cf, Lr"

"Cd, $\mathrm{Hg}, \mathrm{Zn}, \mathrm{As}, \mathrm{Sb}, \mathrm{Pb}, \mathrm{Tl}, \mathrm{Bi}$

"Sn, Ga, Ge, In, Ag"

"B, Si, P"

Figure 5. Definitions and isotopic compositions for the MELCOR groups in NFAC. 


\section{RESULTS}

The moderate and severe PWR release files will be validated against accident calculations from the NRCapproved Individual Plant Examination (IPE) for Calvert Cliffs Nuclear Power Plant [1]. The NFAC PWR severe accident release file (Figure 1) is compared against calculated releases from a small-break Loss of Coolant Accident (LOCA) with early containment failure at Calvert Cliffs, as shown in Figure 6. In Figure 6, the initial 150-minute delay prior to the start of NFAC releases defined in Figure 1 is clearly evident. After this initial delay, the NRC curves rise to release about $8 \%$ Noble Gases and 2\% Halogens over the next 1-hour interval, as is also represented in the NFAC file from Figure 1. The final NFAC total releases of $97 \%$ Noble Gases and $19 \%$ Halogens are very close to the asymptotic limits from Figure 6. Release fractions for the other MELCOR groups are also consistent.

Similarly, the NFAC PWR moderate accident file (Figure 2) can be compared to the Calvert Cliffs IPE plot for a LOCA with late containment failure, as seen in Figure 7. Here there is a delay of about three hours (186 min) before releases begin. The release consists almost entirely of Noble Gases with an asymptotic fraction of about $20 \%$ total release. Thus the PWR moderate accident source terms are quite consistent with published NRC-approved data from the Calvert Cliffs IPE.

The BWR moderate and severe NFAC release files will be validated against NRC-sponsored MELCOR calculations for a station blackout at the Grand Gulf Nuclear Power Plant that were published in an ORNL report [2]. Figure 8 shows Table ES.5 taken from this report that gives the best-estimate release fractions and timing of a severe accident. It is important to note that times in Figure 8 are measured from containment failure and do not include the initial $2580 \mathrm{~min}$ delay interval with no releases present in the NFAC file (Figure 3). The initial delay is followed by release of $63.7 \%$ of the Noble Gases, $1 \%$ for Alkalis, and $1.35 \%$ for the Halogens in the severe BWR release. All of these numbers for the severe BWR release match between NFAC and the NRC-sponsored MELCOR calculations. The moderate BWR accident in NFAC (Figure 4) does not involve containment failure, so that releases are two orders of magnitude smaller and consist almost entirely of volatile isotopes like the Noble Gases and Halogens. This moderate release scenario is also consistent with NRC-sponsored MELCOR calculations performed by ORNL.

The NFAC release files for PWRs and BWRs can also be verified against some more general NRC release estimates from the NUREG-1465 report [3]. Figure 9, which shows Table 3.13 from NUREG1465, details the magnitude and timing of releases expected from a generic PWR severe accident. As usual, the release fractions are organized by MELCOR groups. The release is expected to take place in four distinct phases: gap release, early in-vessel, ex-vessel, and late in-vessel. Time intervals corresponding to these phases for a PWR are 30 minutes, 1.5 hours, 2 hours, and 10 hours, respectively. The initial gap release phase involves only cladding failure but no fuel melting, so that only volatile fission products trapped in the fuel-cladding gap are released. The early in-vessel and ex-vessel phases involve actual fuel melting and constitute the bulk of the releases over the next 3.5 hours. This NRC release fraction distribution and timing is very consistent with the NFAC PWR severe accident release file from Figure 1.

For BWR severe accidents, the generic NRC accident releases are presented in Figure 10, which reproduces Table 3.12 in the NUREG-1465 report [3]. Most of the release fractions in Figure 10 are very similar to the generic PWR severe accident numbers. However, the timing for some parts of the accident sequence is slightly different: gap release (30 minutes), early in-vessel (1.3 hours), ex-vessel (3 hours), and late in-vessel (10 hours). Again, the magnitudes, timing, and number of phases in the NRC BWR severe accident releases fit well with the NFAC severe BWR release file (found in Figure 3). 


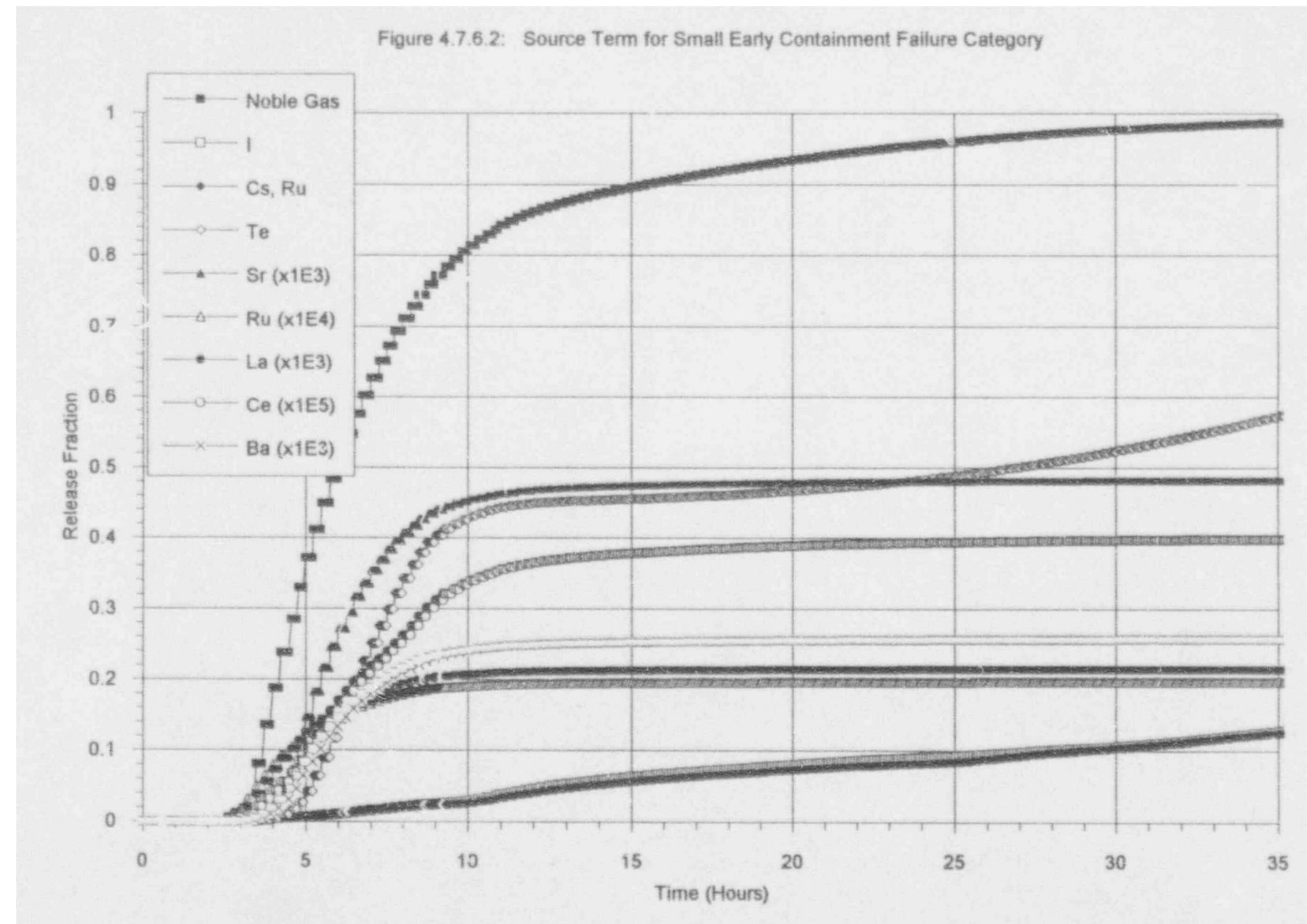

Figure 6. Release fractions and timing for a small LOCA with early containment failure from the Calvert Cliffs IPE report. 
Figure 4.7.6.1: Source Term for Late Containment Faiture Category

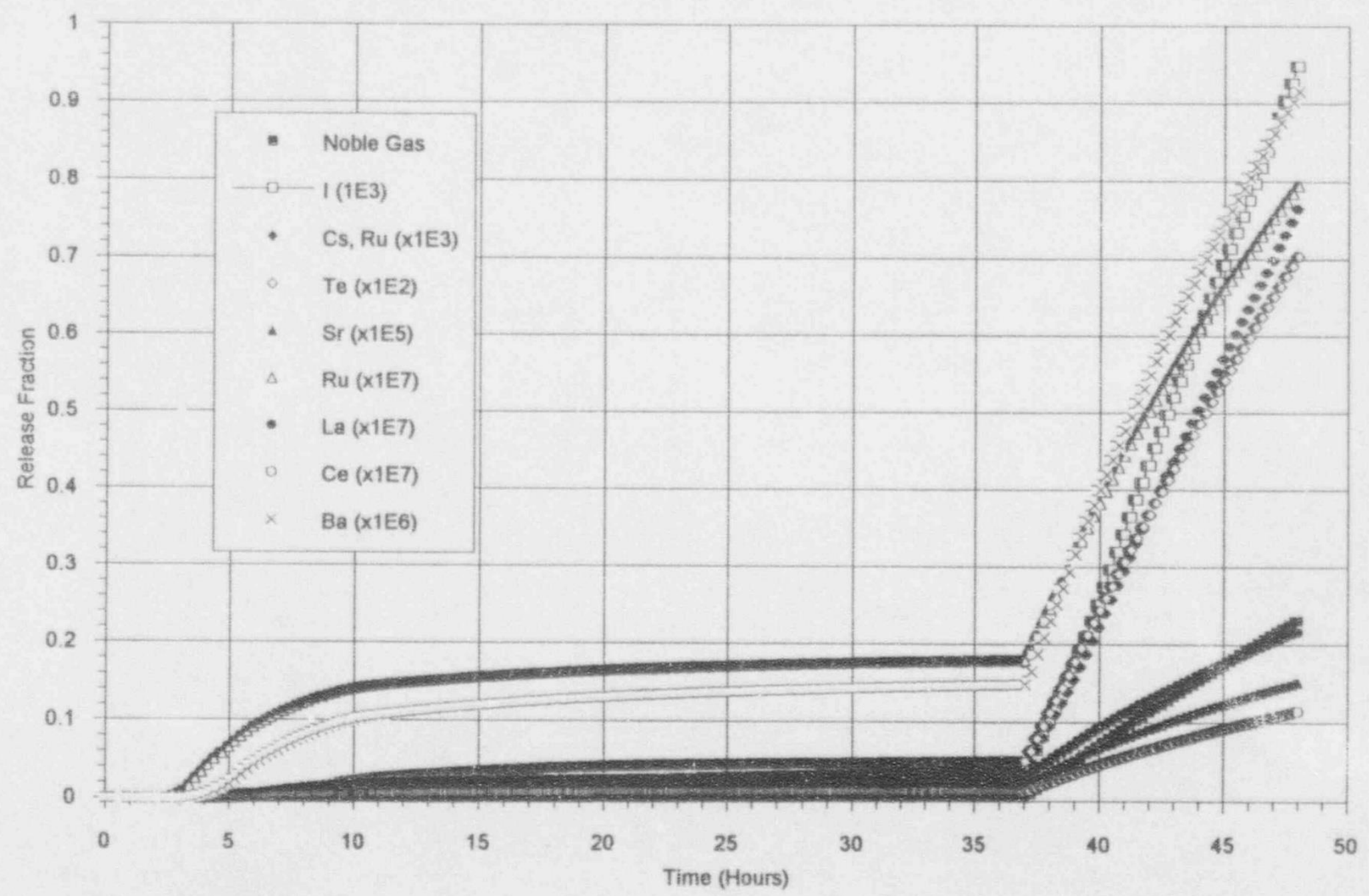

Figure 7. Release fractions and timing for a LOCA with late containment failure from the Calvert Cliffs IPE report. 
Table ES.5. Cumulative source terms released into the environment for the station blackout with the best-estimate deck

\begin{tabular}{ccrrrrrr}
\hline Time after containment failure & & & & & \\
& & $(\mathrm{s})$ & 2,365 & 3,365 & 7,775 & 11,774 & 15,173 \\
& & $(\mathrm{~min})$ & 3.9 & 56 & 130 & 196 & 253 \\
\hline Class & Element & Fraction & Fraction & Fraction & Fraction & Fraction \\
\hline 1 & Noble gases & 0.6374 & 0.7465 & 0.8001 & 0.8264 & 0.8460 \\
2 & $\mathrm{Cs}$ & 0.0034 & 0.0067 & 0.0087 & 0.0095 & 0.0100 \\
3 & $\mathrm{Ba}, \mathrm{Sr}$ & $8 \times 10^{-7}$ & $9.8 \times 10^{-7}$ & $1.1 \times 10^{-6}$ & $1.2 \times 10^{-6}$ & $1.2 \times 10^{-6}$ \\
4 & $\mathrm{I}$ & - & - & - & - & - \\
5 & $\mathrm{Te}$ & 0.0009 & 0.0018 & 0.0024 & 0.0026 & 0.0028 \\
6 & $\mathrm{Ru}$ & $1.4 \times 10^{-10}$ & $1.5 \times 10^{-10}$ & $1.6 \times 10^{-10}$ & $1.6 \times 10^{-10}$ & $1.6 \times 10^{-10}$ \\
7 & $\mathrm{Mo}$ & $1.6 \times 10^{-10}$ & $2.0 \times 10^{-10}$ & $2.4 \times 10^{-10}$ & $2.6 \times 10^{-10}$ & $2.9 \times 10^{-10}$ \\
8 & $\mathrm{Ce}$ & $4.6 \times 10^{-8}$ & $5.8 \times 10^{-8}$ & $6.7 \times 10^{-8}$ & $7.4 \times 10^{-8}$ & $8.2 \times 10^{-8}$ \\
9 & $\mathrm{La}$ & $4.6 \times 10^{-8}$ & $5.7 \times 10^{-8}$ & $6.6 \times 10^{-8}$ & $7.3 \times 10^{-8}$ & $8.2 \times 10^{-8}$ \\
10 & $\mathrm{U}$ & $5.1 \times 10^{-8}$ & $6.3 \times 10^{-8}$ & $7.2 \times 10^{-8}$ & $8.0 \times 10^{-8}$ & $8.8 \times 10^{-8}$ \\
11 & $\mathrm{Cd}$ & $2.8 \times 10^{-5}$ & $3.5 \times 10^{-5}$ & $4.1 \times 10^{-5}$ & $4.5 \times 10^{-5}$ & $5.1 \times 10^{-5}$ \\
12 & $\mathrm{Sn}$ & $2.2 \times 10^{-6}$ & $2.8 \times 10^{-6}$ & $3.3 \times 10^{-6}$ & $3.6 \times 10^{-6}$ & $4.1 \times 10^{-6}$ \\
16 & $\mathrm{CsI}$ & 0.0048 & 0.0091 & 0.0118 & 0.0129 & 0.0135 \\
\hline
\end{tabular}

Notes: All fractions are from the initial inventories of fission products, except for classes 2 and 16 that are from the final inventories.

No releases of class $4(\mathrm{I})$ are predicted. All released I forms class 16 (CsI).

Figure 8. Release fractions and timing for a severe accident at Grand Gulf, from an NRCsponsored ORNL report. 
Table 3.13 PWR Releases Into Containment*

\begin{tabular}{lcccc}
\hline & Gap Release*** & Early In-Vessel & Ex·Vessel & Late In·Vessel \\
\hline Duration (Hours) & 0.5 & 1.3 & 2.0 & 10.0 \\
Noble Gases** & 0.05 & 0.95 & 0 & 0 \\
Halogens & 0.05 & 0.35 & 0.25 & 0.1 \\
Alkali Metals & 0.05 & 0.25 & 0.35 & 0.1 \\
Tellurium group & 0 & 0.05 & 0.25 & 0.005 \\
Barium, Strontium & 0 & 0.02 & 0.1 & 0 \\
Noble Metals & 0 & 0.0025 & 0.0025 & 0 \\
Cerium group & 0 & 0.0005 & 0.005 & 0 \\
Lanthanides & 0 & 0.0002 & 0.005 & 0 \\
\hline
\end{tabular}

- Values shown are fractions of core inventory.

** See Table 3.8 for a listing of the elements in each group

*** Gap release is 3 percent if long-term fuel cooling is maintained.

Figure 9. Release fractions and timing from a generic PWR severe accident, from NRC NUREG1465.

Table 3.12 BWR Releases Into Containment*

\begin{tabular}{lcccc}
\hline & Gap Release*** & Early In·Vessel & Ex·Vessel & Late In·Vessel \\
\hline Duration (Hours) & 0.5 & 1.5 & 3.0 & 10.0 \\
Noble Gases** & 0.05 & 0.95 & 0 & 0 \\
Halogens & 0.05 & 0.25 & 0.30 & 0.1 \\
Alkali Metals & 0.05 & 0.20 & 0.35 & 0.1 \\
Tellurium group & 0 & 0.05 & 0.25 & 0.005 \\
Barium, Strontium & 0 & 0.02 & 0.1 & 0 \\
Noble Metals & 0 & 0.0025 & 0.0025 & 0 \\
Cerium group & 0 & 0.0005 & 0.005 & 0 \\
Lanthanides & 0 & 0.0002 & 0.005 & 0 \\
\hline
\end{tabular}

* Values shown are fractions of core inventory.

** See Table 3.8 for a listing of the elements in each group

*** Gap release is 3 percent if long-term fuel cooling is maintained.

Figure 10. Release fractions and timing from a generic BWR severe accident, from NRC NUREG1465. 


\section{CONCLUSIONS}

The PWR and BWR source terms used by the NFAC module in HPAC have thus been validated against published NRC-approved results from a number of sources. This comparison has included the magnitude and composition of the isotopic release fractions as well as their timing over the course of a severe or moderate accident. Both calculations for facility-specific nuclear power plants and for more generic

reactor categories were involved. It is clear that the NFAC radiological source terms in HPAC are well in line with NRC standards for moderate and severe accidents at PWRs and BWRs.

\section{REFERENCES}

1. B. B. Mrowca, et al., Calvert Cliffs Nuclear Power Plant, Individual Plant Examination(IPE), Summary Report, Baltimore Gas and Electric, December 1993.

2. J. J. Carbajo, Comparison of MELCOR Modeling Techniques and Effects of Vessel Water Injection on a Low-Pressure, Short-Term, Station Blackout at the Grand Gulf Nuclear Station, ORNL/TM12771, Oak Ridge National Laboratory, June 1995.

3. L. Soffer, et al., Accident Source Terms for Light-Water Nuclear Power Plants, NUREG-1465, U.S. Nuclear Regulatory Commission, Washington, DC, February 1995. 


\section{INTERNAL DISTRIBUTION}

1. R. W. Lee

2. R. H. Morris

3. C. D. Sulfredge

\section{EXTERNAL DISTRIBUTION}

4. T. A. Hann, Defense Threat Reduction Agency, DTRA Reachback Division, 8725 John J. Kingman Drive, Ft. Belvoir, VA 22060

5. M. P. Phillips, Defense Threat Reduction Agency, DTRA Reachback Division, 8725 John J. Kingman Drive, Ft. Belvoir, VA 22060

6. M. M. Traynor, Defense Threat Reduction Agency, DTRA Reachback Division, 8725 John J. Kingman Drive, Ft. Belvoir, VA 22060 